\begin{tabular}{|c|c|c|}
\hline & Postgraduate Bosowa University Publishing (PBUP) & $\begin{array}{l}\text { INDONESIAN } \\
\text { JOURNAL }\end{array}$ \\
\hline & $\begin{array}{l}\text { Indonesian Journal of Business and Management } \\
\text { e-ISSN: } 2460-3767 \quad p \text {-ISSN: } 2656-6885\end{array}$ & \\
\hline 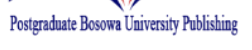 & https://postgraduate.universitasbosowa.ac.id/index.php/jbm & $\begin{array}{l}\text { OF BUSINESS } \\
\text { AND MANAGEMENT }\end{array}$ \\
\hline
\end{tabular}

\title{
ANALISIS MOTIVASI DAN LINGKUNGAN ORGANISASI TERHADAP PENERAPAN GOOD CORPORATE GOVERNANCE MELALUI KEPEMIMPINAN PADA SEKRETARIAT KABUPATEN MAMUJU TENGAH
}

\section{Analysis of Motivation And Organizational Environment On The Implementation of Good Corporate Governance Through Leadership In The Secretariat Central Mamuju District}

\author{
Andi Dian Fajriah ${ }^{1}$, Chahyono ${ }^{2}$, Herminawaty Abubakar ${ }^{2}$ \\ ${ }^{1}$ Sekretariat Daerah Kabupaten Mamuju Tengah \\ ${ }^{2}$ Program Studi Manajemen Program Pascasarjana Universitas Bosowa
}

Email: andidian3393@gmail.com

Diterima: 24 Oktober 2021/Disetujui: 24 Desember 2021

\begin{abstract}
ABSTRAK
Tujuan penelitian ini untuk mengetahui sejauh mana pengaruh motivasi dan lingkungan organisasi terhadap penerapan good corporate governance melalui kepemimpinan pada Kantor Sekretariat Daerah Kabupaten Mamuju Tengah. Jumlah responden sebanyak 50 orang yaitu pegawai pada kantor tersebut. Metode analisis yang digunakan adalah regresi berganda melalui pendekatan jalur atau path. Hasil analisis menunjukan bahwa motivasi dan lingkungan organisasi berpengaruh positif dan signifikat terhadap kepemimpinan dan penerapan good corporate governance secara langsung, artinya koefisien regresi yang dihasilakan bertanda positif dengan tingkat signifikan yang lebih kecil dari signifikasi standar jika dihubungkan secara langsung atau tanpa dimediasi variable lain. Kepemimpinan juga memiliki pengaruh positif dan signifikat terhadap penerapan good corporate governance secara langsung, koefisien regresi yang dihasilakan bertanda positif dengan tingkat signifikan yang lebih kecil dari signifikasi standar jika dihubungkan secara langsung atau tanpa dimediasi variable lain. Untuk mengukur hubungan tidak langsung antara motivasi dan lingkungan organisasi terhadap penerapan good corporate governance melalui kepemimpinan hasil yang ditunjukan bahwa motivasi dan lingkungan organisasi memiliki hubungan positif dan signifikan terhadap penerapan good corporate governance melalui kepemimpinan. Hubungan tidak langsung memiliki koefisien regresi yang lebih besar dari hubungan langsung yang terjadi. Hal ini diperoleh dari nilai koefisien total yang lebih besar.
\end{abstract}

Kata Kunci: Motivasi, Lingkungan Organisasi, Kepemimpinan, Penerapan Good Corporate Governance

\begin{abstract}
The purpose of this study was to determine the extent of the influence of motivation and organizational environment on the implementation of good corporate governance through leadership at the Regional Secretariat Office of Central Mamuju Regency. The number of respondents as many as 50 people, namely employees in the office. The analytical method used is multiple regression through the path or path approach. The results of the analysis show that motivation and organizational environment have a positive and significant effect on leadership and the implementation of good corporate governance directly, meaning that the resulting regression coefficient is positive with a significant level that is smaller than the standard significance if it is connected directly or without being mediated by other variables. Leadership also has a positive and significant influence on the implementation of good corporate governance directly, the resulting regression coefficient is positive with a significant level that is smaller than the standard significance if it is connected directly or without being mediated by other variables. To measure the indirect relationship between motivation and organizational environment on the implementation of good corporate governance through leadership, the results show that motivation and organizational environment have a positive and significant relationship to the implementation of good corporate governance through
\end{abstract}


Analisis Motivasi dan Lingkungan Organisasi Terhdap..... (Andi Dian Fajriah, Chahyono, Herminawaty Abubakar) leadership. The indirect relationship has a regression coefficient that is greater than the direct relationship that occurs. This is obtained from the larger total coefficient value.

Keywords: Motivation, Organizational Environment, Leadership, Implementation Good Corporate Governance

(c) 1 () This work is licensed under Creative Commons Attribution License 4.0 CC-BY International license

\section{PENDAHULUAN}

Undang-Undang Nomor 25 Tahun 2009 pasal 3 mengamanatkan bahwa tujuan dari pelayanan publik adalah: (1) terwujudnya kesetaraan atas hak, kewajiban, tanggungjawab dan wewenang seluruh stakeholder penyelenggara pelayanan; (2) terciptanya penyelenggaraan pelayanan yang baik dan berkualitas sesuai dengan ketentuan dan asas umum; (3) terwujudnya pelayaanan publik yang sesuai dengan peraturan perundang-undangan;dan (4) terwujudnya perlindungan dan kepastian hukum. ASN juga mengharuskan untuk menciptakan kondisi lingkungan aparatur yang bersih dan bebas dari korupsi, kolusi dan nepotisme seperti yang tertuang dalam

Undang-Undang Nomor 28 Tahun 1999. Pasal 3 menjelaskan bahwa penyelenggara negara harus taat akan asas umum, yaitu asas kepastian hukum, tertib penyelenggaraan negara, kepentingan umum, keterbukaan, proporsionalitas, profesionalitas dan akuntabilitas.

Undang-Undang Nomor 5 Tahun 2014 tentang aparatur sipil negara yang berkaitan dengan Manajemen aparatur sipil negara diselenggarakan yang berdasarkan pada kualifkasi, kompetensi, dan kinerja secara adil dan wajar dengan tanpa membedakan latar belakang poltik, ras, warna kulit, agama, asal-usul, jenis kelamin, status pernikahan, umum, atau kondisi kecacatan. Pegawai aparatur sipil negara diserahi tugas untuk melaksanakan tugas pelayanan publik, tugas pemerintahan, dan tugas pembangunan tertentu.

Upaya dalam meningkatkan kualitas sumber daya manusia dapat diarahkan pada aspek kualitas dan aspek kuantitas. Aspek kualitas yang dimaksud adalah aspek fisik dan aspek non fisik yang menyangkut kemampuan bekerja, berfikir dan keterampilan yang dimiliki. Sedangkan aspek kuantitas pada sumber daya manusia menyakut kemampuan mutu yang ada pada pegawai. Aparatur sipil negara harus memiliki integritas, profesional, netral dan bebas dari intervensi politik, bersih dari praktik korupsi kolusi, dan nepotisme, sehingga dalam menyelenggarakan pelayanan publik bagi masyarakat mampu menjalankan peran sebagai unsur perekat persatuan dan kesatuan bangsa berdasarkan Pancasila dan Undang-Undang Dasar Negara Republik Indonesia Tahun 1945.

Dalam menwujudkan karakter pemimpin guna mewujudkan Good Governance, maka prinsip yang harus diterapkan bagi aparat sipil negara yaitu Transparansi dalam realitas kehidupan setiap instansi pemerintah, hal ini menggambarkan bahwa transparansi merupakan slogan untuk mendapatkan dukungan publik namun dibalik semua itu transparansi sebenarnya hanya merupakan penunjang program sebagai pendukung untuk menarik minat publik itu sendiri. Akan tetapi yang menjadi keutamaan seorang pimpinan pada Sekretariat Daerah Kabupaten Mamuju Tengah harus siap secara menjaga kondisi roda kepemerintahannya agar instansi Sekretariat Daerah dapat berjalan dengan baik, dan memberikan pelayanan kepada publik sesuai tuntutan dari good governance. Kepala Sekretariat Daerah Kabupaten Mamuju Tengah harus mampu menjalankan roda pemerintahan khususnya diinstansi dengan berpijak terhadap visi dan misi serta tujuan dari kelembagaan tersebut, selain itu pula senantiasa mampu menjalankan aturan yang berlaku dan mampu membangun komunikasi serta kompetensi para aparat sipil negara di Sekretariat Daerah Kabupaten Mamuju Tengah.

Berdasarkan fakta pada Sekretariat Daerah Kabupaten Mamuju Tengah pemimpin memiliki pengaruh yang sangat dominan terhadap motivasi dan good governance, semua kegiatan atau pekerjaan yang ada di Sekretariat Daerah Kabupaten Mamuju Tengah mengacu pada arah dari kepala Sekretariat Daerah Kabupaten Mamuju Tengah. Menurut staf pegawai di Sekretariat Daerah Kabupaten Mamuju Tengah mengatakan bahwa pembagian tugas yang diberikan oleh pemimpin kepada para bawahannya kandang tidak seimbang sehingga sehingga pekerjaan pun menjadi menumpuk dan dalam menyelesaikan tugas-tugas tersebut pun menjadi lambat.

Lingkungan organisasi merupakan hal terpenting dalam peningkatan good governance. Faktor yang juga perlu dinilai terhadap kemampuan aparat sipil negara dalam meningkatkan pelayanan adalah kemampuan penilai dan hubungan khusus antara pihak atau lembaga penilai dengan yang dinilai. Yang dimaksud dalam kemampuan penilai adalah tingkat pendidikan, pengetahuan, pengalaman, dan penguasaan terhadap materi yang dinilai. Ia mengetahui secara tepat apa yang hendak ia nilai, dan cara ia memberi penilaian. Di masa lampau, ketepatan penilaian seringkali tidak diperhatikan sebab penilai atau pemimpin tidak mengetahui secara benar apa materi yang dinilai dan bagaimana menilainya. Karena ketidakmampuan tersebut maka muncul penilaian yang sangat didasarkan kepada keeratan hubungan pribadi antara pihak yang menilai dengan yang dinilai. Dalam kondisi semacam ini hasil penilaian tidak dapat digunakan.

Lingkungan kerja merupakan tempat para pegawai untuk bekerja dan menjadi faktor dalam meningkatkan kinerja. Lingkungan kerja salah satu kondisi material dan psikologis yang ada dalam organisasi. Oleh karena itu organisasi harus menyediakan lingkungan kerja yang memadai seperti lingkungan kerja yang nyaman dan bersih, selain itu pula perusahaan juga membangun lingkungan kerja non fisik (suasana kerja, kesejahteraan kerja dan hubungan antar sesama karyawan, antar karyawan dengan pimpinan serta tempat ibadah). 
Motivasi kerja merupakan suatu kekuatan yang mendorong seseorang yang timbul dari dalam diri sendiri untuk melakukan suatu kegiatan untuk mencapai tujuan yang diinginkan. Menurut McClelland dalam Robbins, (2006:222) seseorang dianggap mempunyai motivasi apabila dia mempunyai keinginan berprestasi lebih baik daripada yang lain pada banyak situasi. Dengan adanya motivasi dalam dirinya seorang pegawai dapat memacu semangat kerja dengan sehingga mempengaruhi kemajuan dan keberhasilan suatu organisasi.

Hasil pengamatan awal pada motivasi kerja, para pegawai masih kurang menyukai pekerjaan yang beresiko tinggi dimana pekerjaan yang beresiko tinggi akan menimbulkan anggapan atas ketidakmampuan jika mengalami kegagalan dalam pekerjaan, salah satunya adalah tuntutan pencapain target pertahun. Rendahnya motivasi baik dalam prestasi menjadikan pegawai Sekretariat Daerah Kabupaten Mamuju Tengah kurang terpacu untuk berkreatif dan berinovatif dalam pekerjaan, disebabkan kurangnya dukungan pegawai lainnya baik berupa dukungan fikiran serta tenaga kurang mendapat respon dikarenakan mereka menganggap kegiatan tersebut akan menyusahkan dan bukan urusannya mereka.

Tantangan yang harus dihadapai oleh ASN terhadap aspek politik yang saat ini masih menjadi pola jabatan birokrasi pemerintahan, sudah bukan lagi menjadi ketakutan dalam kinerja. Pemerintahan jokowi sudah menerapkan satu kebijakan terhadap jabatan birokrasi, yaitu melepaskan jabatan politiknya bagi pejabat yang diangkat melalui partai politik. Sehingga kinerja pelayanan publik dapat berjalan secara professional dan perhatian atas kinerja ASN menjadi lebih focus dan tercapai sesuai dengan ketentuannya. ASN mempunyai peluang yang besar untuk meningkatkan kualitas dirinya dalam proses pengembangan karir jabatannya. Aspek politik sedikit tidak berpengaruh terhadap kinerja ASN, kriminalisasi dan diskriminasi serta peran like and dislike sudah bukan menjadi isu penting dalam pengelolaan dan manajemen ASN. Tuijuan penelitian ini adalah untuk menganalisis motivasi dan lingkungan organisasi terhadap penerapan good corporate governance melalui kepemimpinan pada sekretariat kabupaten Mamuju Tengah.

\section{METODE}

\section{a. Jenis Penelitian}

Jenis penelitian ini adalah eksplanatoris atau penjelasan yang menunjukkan kedudukan variabelvariabel yang diteliti serta hubungan antara satu variabel dengan variabel yang lainnya (Sugiyono, 2006).

Meskipun model penelitian ini uraiannya mengandung deskripsi, akan tetapi sebagai penelitian relasional fokusnya terletak kepada penjelasan terhadap pengaruh antar variabel. Unit analisis data yang dipergunakan dalam penelitian ini adalah setiap individu (Singarimbun dan Effendi, 2006). Individu yang dimaksud disini adalah pegawai yang bekerja pada Kantor Sekretariat Daerah Kabupaten Mamuju Tengah.

\section{b. Populasi dan Sampel}

Menurut Sugiyono (2006) populasi adalah wilayah generalisasi yang terdiri atas objek-objek yang mempunyai kualitas dan karakteristik tertentu yang ditetapkan oleh peneliti untuk dipelajari dan kemudian ditarik kesimpulannya, sehingga populasi penelitian mencakup jumlah keseluruhan pegawai Kantor Sekretariat Daerah Kabupaten Mamuju Tengah. yang berjumlah 50 orang. Berdasarkan jumlah populasi pegawai pada Kantor Sekretariat Daerah Kabupaten Mamuju Tengah berjumlah 50 orang. Dengan demikian populasi penelitian seluruh karyawan yang berjumlah 50 orang. Keseluruhan populasi tersebut dijadikan responden kecuali pimpinan dan peneliti sendiri, sehingga jumlah responden yang dijadikan sampel 50 orang.

\section{c. Jenis dan Sumber Data}

Menurut Muhamad (2008: 99-100) jenis data terdiri dari data kualitatif dan data kuantitatif :

1) Data kualitatif adalah data yang tidak dinyatakan dalam bentuk angka. Penelitian kualitatif lebih bersifat deskriptif dan data yang terkumpul berbentuk kata-kata atau gambar, sehingga tidak menekankan pada angka.

2) Data kuantitatif adalah data dalam bentuk angkaangka dan analisisnya menggunakan statistik. Penelitian kuanitatif lebih bersifat deduktif dan data yang terkumpul selanjutnya dianalisis secara kuantitatif dengan menggunakan teknik statistik sehingga dapat disimpulkan.

Sumber data yang digunakan dalam penelitian ini terdiri dari data primer dan data sekunder :

1) Data primer adalah data yang diperoleh langsung dari subjek penelitian dengan menggunakan alat pengukuran atau alat pengambilan data langsung pada subjek sebagai sumber informasi yang dicari (Azwar, 1998: 91). Dalam penelitian ini, data primer adalah data yang diperoleh secara langsung dari pegawai Kantor Sekretariat Daerah Kabupaten Mamuju Tengah yang dijadikan sebagai sampel (subjek penelitian). Data primer yang dimaksud yaitu tanggapan responden mengenai kepemimpinan, lingkungan organisasi, motivasi dan penerapan good governance.

2) Data sekunder adalah data yang diperoleh dari pihak lain, tidak langsung diperoleh peneliti dari subjek penelitiannya (Azwar, 1998: 91). Seperti dokumentasi atau laporan yang telah tersedia. Data sekunder adalah data yang diambil dari dokumendokumen, berupa jumlah pegawai.

\section{d. Teknik Pengumpulan Data}

Metode pengumpulan data digunakan memperoleh data yang sesuai dengan jenis dan sumber data, dalam penelitian ini digunakan beberapa metode sebagai berikut:

1) Observasi adalah metode pengumpulan data dengan mengadakan pengamatan langsung ke objek penelitian. Menurut Pabundu (2005: 44) observasi adalah teknik pengumpulan data dengan melakukan pengamatan dan pencatatan secara sistematis 
terhadap gejala atau fenomena yang ada pada objek penelitian.

2) Kuesioner adalah metode pengumpulan data yang dilakukan dengan cara memberi seperangkat pertanyaan atau pernyataan tertulis kepada responden untuk dijawabnya dalam Sugiyono (2008: 199).

3) Dokumentasi

Dokumentasi digunakan untuk mengumpulkan data berupa data-data tertulis yang mengandung keterangan dan penjelasan serta pemikiran sesuai dengan masalah penelitian (Muhamad, 2008: 152). Dokumentasi seperti literatur buku, laporan, atau bukti-bukti lain yang sesuai dengan penelitian.

4) Wawancara

Metode pengumpulan data dengan tanya jawab yang dikerjakan dengan sistematis dan berlandaskan pada tujuan penelitian (Pabundu, 2005: 49). Dalam penelitian ini, wawancara dilakukan dengan cara mengadakan wawancara langsung pada beberapa pegawai pada Kantor Sekretariat Daerah Kabupaten Mamuju Tengah guna memperoleh informasi dalam penelitian ini.

\section{e. Teknis Analisis Data}

Untuk memecahkan masalah pokok sekaligus untuk membuktikan hipotesis yang diajukan dapat digunakan metode analisis sebagai berikut:

1) Metode analisis deskriptif yaitu dengan cara menganalisa gambaran kepemimpinan, lingkungan organisasi, motivasi dan good corporate governance pada pegawai Sekretariat Daerah Kabupaten Mamuju Tengah.

2) Path Analysis (Analisis Jalur) digunakan untuk mengetahui kepemimpinan, lingkungan organisasi, motivasi dan good corporate governance pada pegawai Sekretariat Daerah Kabupaten Mamuju Tengah.

\section{HASIL DAN PEMBAHASAN}

\section{1) Karakteristik Responden}

Responden dalam penelitian ini adalah Pegawai Lingkup Kantor Sekretariat Daerah Kabupaten Mamuju Tengah yang berjumlah sebanyak 50 orang yang penulis berikan angket mengenai penelitian ini.

Karakteristik responden yang diteliti dalam penelitian ini meliputi jenis kelamin responden, umur responden dan tingkat pendidikan responden. Pengetahuan mengenai karakteristik responden sangat perlu sebagai barometer penguatan hasil penelitian secara realistis. Untuk memperjelas karakteristik responden yang dimaksud, maka disajikan karakteristik responden dalam bentuk tabel sebagai berikut :

Hasil penelitian ini menunjukkan bahwa dari 50 orang responden yang diambil sebagai sampel, terdiri dari laki-laki dan perempuan dengan proporsi seperti tampak pada Tabel berikut:
Tabel 1. Karakteristik Responden Berdasarkan Jenis Kelamin

\begin{tabular}{ccc}
\hline Jenis Kelamin & Frekuensi (orang) & Persentase $(\%)$ \\
\hline Perempuan & 22 & 44 \\
\hline Laki-Laki & 28 & 56 \\
\hline Jumlah & 50 & 100 \\
\hline Sumber: Hasil Penelitian, 2021 &
\end{tabular}

Berdasarkan tabel tersebut yaitu deskripsi identitas responden berdasarkan jenis kelamin, menunjukkan bahwa responden yang berjenis kelamin laki-laki sebanyak 28 orang dengan persentase sebesar $56 \%$, dan yang berjenis kelamin perempuan sebanyak 22 orang dengan persentase sebesar $44 \%$.

Usia merupakan salah satu faktor yang mempengaruhi pengembangam diri. Seseorang akan mengalami peningkatan kemampuan seiring dengan meningkatnya usia, akan tetapi selanjutnya akan mengalami penurunan kamampuan pada titik umur tertentu. Berdasarkan hal tersebut maka dikenal adanya umur produktif dan umur nonproduktif. Umur produktif adalah umur dimana seseorang memiliki kemampaun untuk menghasilkan produk maupun jasa. Usia produktif 20 - 45 tahun masih memiliki semangat yang tinggi dan mudah mengadopsi hal-hal baru. Berbeda dengan pekerja yang telah berusia lanjut (di atas 50 tahun). Mereka yang berusia lanjut cenderung fanatik terhadap tradisi dan sulit untuk diberikan pengertian-pengertian yang dapat mengubah cara berfikir, cara kerja dan cara hidupnya. Berikut disajikan jenis responden berdasarkan tingkat umur pada Sekertariat Kabupaten Mamuju Tengah:

Tabel 2 Karakteristik responden berdasarkan Usia

\begin{tabular}{|c|c|c|}
\hline Usia (tahun) & $\begin{array}{l}\text { Jumlah Responden } \\
\text { (orang) }\end{array}$ & Persentase (\%) \\
\hline $20-30$ & 6 & 12 \\
\hline $31-40$ & 20 & 40 \\
\hline $41-50$ & 16 & 32 \\
\hline$>50$ & 8 & 16 \\
\hline Jumlah & 50 & 100 \\
\hline
\end{tabular}

Sumber: Hasil Penelitian, 2021

Dari tabel tersebut dapat lihat bahwa kebanyakan responden berusia 31-40 tahun yaitu 20 orang dengan persentase sebesar $40 \%$. Selanjutnya responden dengan usia 20-30 tahun sebanyak 6 orang dengan persentase sebesar $12 \%$. Pada usia 41-50 tahun jumlah responden sebanyak 16 orang dengan persentase sebesar $32 \%$, dan untuk usia diatas 50 tahun sebanyak 8 orang dengan persentase sebesar $16 \%$.

Semakin tinggi tingkat pendidikan pegawai maka akan semakin tinggi kualitas sumberdaya manusia. Oleh karena itu, dengan semakin tingginya pendidikan pegawai maka diharapkan pengembangan kemampuan pegawai dapat sampai hasil yang di inginkan. Dari pernyataan tersebut menunjukkan bahwa tingkat pendidikan merupakan salah satu faktor yang mempengaruhi seseorang dalam pekerjaan yang digelutinya. Seseorang yang mempunyai tingkat pendidikan yang tinggi dapat melaksakan kerjanya dengan baik karena ditunjang 
dengan ilmu pengetahuan secara konsep yang akan menunjang pengalaman kerjanya. Berikut disajikan jenis responden berdasarkan tingkat pendidikan pada pegawai Sekretariat Kabupaten Mamuju Tengah:

Tabel 3 Karakteristik Responden Berdasarkan Tingkat Pendidikan

\begin{tabular}{lcc}
\hline $\begin{array}{c}\text { Tingkat Pendidikan } \\
\text { Responden }\end{array}$ & $\begin{array}{c}\text { Frekuensi } \\
\text { (orang) }\end{array}$ & Persentase (\%) \\
\hline SMA & 10 & 20 \\
\hline Diploma & 5 & 10 \\
\hline Sarjana & 25 & 50 \\
\hline Pascasarjana & 10 & 20 \\
\hline \multicolumn{1}{c}{ Jumlah } & 50 & 100 \\
\hline Sumber: Hasil Penelitian, 2021 &
\end{tabular}

Dari Tabel 3 di atas menunjukkan bahwa pada umumnya responden memiliki tingkat pendidikan sarjana, dimana terdapat sebanyak 25 responden atau $50 \%$. Sedangkan yang memiliki tingkat pendidikan terendah yaitu SMA sebanya 10 orang atau sebesar $20 \%$. Tingkat pendidikan diploma sebanyak 5 orang atau $10 \%$, dan untuk tingkat pendidikan pascasarjana sebanyak 10 orang atau $20 \%$.

\section{2) Pengaruh Motivasi Terhadap Kepemimpinan}

Dari hasil pengujian regresi yang dilakukan dalam penelitian ini diketahui bahwa variabel motivasi memiliki nilai positif terhadap variabel kepemimpinan pada Kantor Sekretariat Daerah Kabupaten Mamuju Tengah. Dapat disimpulkan bahwa motivasi memiliki pengaruh yang searah terhadap kepemimpinan. Makin besar variabel motivasi maka semakin besar juga kenaikan variabel kepemimpinan. Nilai derajat signifikan yang dihasilkan lebih kecil dari standar signifikan yang ditentukan. Indikator-indikator yang digunakan sebagai ukuran variabel pendidikan reability dan valid. Hubungan ini merupaan hubungan langsung.

Asumsi ini tidak sejalan dengan hasil penelitian yang dilakukan oleh Claude Fernet, dkk (2015) yang menjelaskan hasil dari penelitiannya yaitu pemberian motivasi dapat pengaruh yang positif kepada kepemempinan dalam sebuah organisasi. Pimpinan seharusnya dapat menjadi teladan sebagai motivasi bagi bawahannya.

\section{3) Pengaruh Lingkungan Organisasi Terhadap Kepemimpinan}

Varibael lingkungan organisasi memiliki pengaruh yang positif terhadap kepemimpinan pada Kantor Sekretariat Daerah Kabupaten Mamuju Tengah. Hal ini ditunjukan oleh hasil regresi yang menunjukan nilai positif dengan derajat signifikan yang lebih kecil dari standar signifikan yang telah ditentukan dalam penelitian ini. Hasil pengujian reabilitasi dan validasi juga menunjukan nilai yang positif. Hal ini membuktikan bahwa indikator-indikator yang yang digunakan dalam menilai variabel peatihan kredibel.

Hasil penelitian ini mengamsumsikan bahwa lingkungan organisasi dapat menjadi pendukung kepemimpinan. Dengan dukungan lingkungan organiasi, maka kepemimpinan akan berjalan sebagaimana mestinya. Lingkungan organisasi yang memberi rasa nyaman bagi pegawai dan pimpinan tentunya akan dapat menjadi pendorong pengembangan diri bagi pegawai maupun pimpinan.

Hasil ini tentunya sejalan dengan teori para ahli yang mengatakan bahwa lingkungan organisasi merupakan segala sesuatu yang dapat mempengaruhi kelangsungan, eksistensi, keberadaan, dan lain-lain termasuk kepemimpinan yang menyangkut organisasi baik da dari dalam maupun dari luar. Penelitian ini menghubungkan antara lingkungan organisasi dengan kepemimpinan, yang merupakan penelitian baru karena peneliti tidak menemukan literasi penelitian yang terhadulu yang menghubungkan variabel lingkungan organisasi dengan variabel kepemimpinan.

\section{4) Pengaruh Motivasi Terhadap Good Corporate Governance}

Variabel motivasi terhadap good corporate governance memiliki pengaruh yang positif. Hal ini sesuai dengan hasil regresi yang ditujunkan bernilai positif dimana derajad signifikan lebih kecil dari nilai signifikan yang telah ditentukan. Indikator-indikator yang digunakan untuk mengukur variabel pendidikan terhadap kinerja kredibel, yang menunjukan nilai lebih besar dari nilai standar yang ditentukan untuk mengukur kekuatan validasi dan reabilitasinya.

Hasil penelitian ini menggambarkan hubungan langsung yang searah antara motivasi dan good corporate governance pada lingkup Kantor Sekretariat Daerah Kabupaten Mamuju Tengah. Makin tinggi motivasi di berikan maka penerapan good corporate governance makin meningkat, sehingga dapat diasumsikan bahwa untuk menerapkan good corporate governance dibutuhkan motivasi sebagai variabel pendukungnya.

Hasil yang ditunjukan dalam penelitian ini sejalan dengan teori motivasi yang dikemukakan oleh para ahli yaitu merupakan suatu keadaan atau kondisi yang mendorong, merangsang atau menggerakan seseorang untuk melakukan sesuatu atau kegiatan yang dilakukannya sehingga ia dapat mencapai tujuannya. Pencapaian tujuan organisasi tentunya gambaran umum dari Good Corporate Governance yang juga menyangkut kelangsungan organisasi. Hubungan motivasi dengan Good Corporate Governance secara teori adalah hubungan yang searah atau mendukung satu sama lain.

\section{5) Pengaruh Lingkungan Organisasi Terhadap Good Corporate Governance}

Varibael lingkungan organisasi memiliki pengaruh yang positif terhadap good corporate governance pada Kantor Sekretariat Daerah Kabupaten Mamuju Tengah. Hal ini ditunjukan oleh hasil regresi yang menunjukan nilai positif dengan derajat signifikan yang lebih kecil dari standar signifikan yang telah ditentukan dalam penelitian ini. Hasil pengujian reabilitasi dan validasi juga menunjukan nilai yang positif. Hal ini membuktikan bahwa indikator-indikator yang yang digunakan dalam menilai variabel peatihan kredibel. 
Hasil penelitian ini menggambarkan hubungan langsung yang searah antara lingkungan organisasi dan good corporate governance pada lingkup Kantor Sekretariat Daerah Kabupaten Mamuju Tengah. Makin besar variabel lingkungan organisasi di berikan maka penerapan good corporate governance makin meningkat, sehingga dapat diasumsikan bahwa untuk menerapkan good corporate governance dibutuhkan lingkungan organisasi yang baik sebagai variabel pendukungnya.

Hasil penelitian ini juga memiliki kesesuaian secara teori antara lingkungan organisasi dan Good Corporate Governance. Dimana lingkungan organisasi segala hal yang dapat mempengaruhi kelangsungan, eksistensi, keberadaan, dan lain-lain termasuk Good Corporate Governance yang menyangkut organisasi baik da dari dalam maupun dari luar. Peran lingkungan organisasi tentunya menunjang penerapan Good Corporate Governance dalam sebuah organisasi. Penelitian ini merupakan penelitian yang baru, karena peneliti tidak menemukan literasi penelitian terdahulu yang menghubungkan antara variabel lingkungan organisasi dengan variabel Good Corporate Governance.

\section{6) Pengaruh Kepemimpinan Terhadap Good Corporate Governance}

Varibael kepemimpinan memiliki pengaruh yang positif terhadap Good Corporate Governance pada Kantor Sekretariat Daerah Kabupaten Mamuju Tengah. Hal ini ditunjukan oleh hasil regresi yang menunjukan nilai positif dengan derajat signifikan yang lebih kecil dari standar signifikan yang telah ditentukan dalam penelitian ini. Hasil pengujian reabilitasi dan validasi juga menunjukan nilai yang positif. Hal ini membuktikan bahwa indikator-indikator yang yang digunakan dalam menilai variabel kepemimpinan kredibel.

Hasil penelitian ini menggambarkan hubungan langsung yang searah antara kepemimpinan dan good corporate governance pada lingkup Kantor Sekretariat Daerah Kabupaten Mamuju Tengah. Makin baik kepemimpinan diterapkan maka penerapan good corporate governance makin meningkat, sehingga dapat diasumsikan bahwa untuk menerapkan good corporate governance dibutuhkan kepemimpinan yang baik sebagai variabel pendukungnya.

Penelitian ini sejalan dengan teori para ahli mengenai kepemimpinan dan Good Corporate Governance, yang menyatakan bahwa kepemimpinan adalah kemampuan untuk mempengaruhi suatu kelompok menuju pencapaian sebuah visi atau tujuan yang ditetapkan. Sedaangkan Good Corporate Governance adalah suatu sistem yang mengelola, mengatur serta mengawasi proses pengendalian organisasi yang berjalan secara berkesinambungan (sustainable) untuk pencapaian tujuan organisasi. Tentunya penerapan Good Corporate Governance dipengaruhi oleh kepemimpinan dalam sebuah organisasi. Penerapan Good Corporate Governance tidak mungkin tercapai tanpa adanya konsep kepemimpinan yang baik dalam organisasi. Penelitian ini merupakan penelitian yang baru, karena peneliti tidak menemukan literasi penelitian terdahulu yang menghubungkan antara variabel kepemimpinan dengan variabel Good Corporate Governance.

\section{7) Pengaruh Motivasi Terhadap Good Corporate Governance Melalui Kepemimpinan}

Variabel motivasi melalalui kepemimpinan memiliki pengaruh yang positif terhadap Good Corporate Governance pada Kantor Sekteraiat Daerah Mamuju Tengah. Hal ini ditunjukan oleh hasil regresi yang menunjukan nilai positif dengan derajat signifikan yang lebih kecil dari standar signifikan yang telah ditentukan dalam penelitian ini. Disimpulkan bahwa jika motivasi dihubungkan ke variabel good corporate governance melalui variabel kepemimpinan, maka akan mempengaruhi secara positif. Hubungan ini dikatakan hubungan tidak langsung antara variabel motivasi terhadap variabel Good Corporate Governance.

Nilai total yang ditunjukan hubungan tidak langsung ini lebih besar terhadap hubungan langsung. Sehingga di asumsikan bahwa untuk meningkatkan Good Corporate Governance maka lebih baik menghubungkan motivasi melalui kepemimpinan terhadap Good Corporate Governance pada Kantor Sekretariat Daerah Kabupaten Mamuju Tengah.

Penelitian ini merupakan penelitian yang baru, karena peneliti tidak menemukan literasi penelitian terdahulu yang menghubungkan antara variabel motivasi dengan variabel Good Corporate Governance melalui variabel kepemimpinan.

\section{8) Pengaruh Lingkungan Organisasi Terhadap Good Corporate Governance Melalui Kepemimpinan \\ Variabel lingkungan organisasi melalalui} kepemimpinan memiliki pengaruh yang positif Good Corporate Governance pada Kantor Sekretariat Daerah Kabupaten Mamuju Tengah. Hal ini ditunjukan oleh hasil regresi yang menunjukan nilai positif dengan derajat signifikan yang lebih kecil dari standar signifikan yang telah ditentukan dalam penelitian ini. Disimpulkan bahwa jika lingkungan organisasi dihubungkan ke variabel Good Corporate Governance melalui variabel kepemimpinan, maka akan mempengaruhi secara positif. Hubungan ini dikatakan hubungan tidak langsung antara variabel lingkungan organisasi terhadap variabel Good Corporate Governance pada Kantor Sekretariat Daerah Kabupaten Mamuju Tengah.

Nilai total yang ditunjukan hubungan tidak langsung ini lebih besar terhadap hubungan langsung. Sehingga di asumsikan bahwa untuk meningkatkan Good Corporate Governance maka lebih baik menghubungkan lingkungan organisasi melalui kepemimpinan terhadap Good Corporate Governance pada Kantor Sekretariat Daerah Kabupaten Mamuju Tengah.

Penelitian ini merupakan penelitian yang baru, karena peneliti tidak menemukan literasi penelitian terdahulu yang menghubungkan antara variabel 
lingkungan organisasi dengan variabel Good Corporate Governance melalui variabel kepemimpinan.

\section{KESIMPULAN DAN SARAN}

Hasil penelitian dapat disimpulkan bahwa motivasi memiliki pengaruh yang searah terhadap kepemimpinan. Makin besar variabel motivasi maka semakin besar juga kenaikan variabel kepemimpinan. Nilai derajat signifikan yang dihasilkan lebih kecil dari standar signifikan yang ditentukan. Indikator-indikator yang digunakan sebagai ukuran variabel motivasi reability dan valid. Hubungan ini merupaan hubungan langsung.

\section{DAFTAR PUSTAKA}

Azwar, Saifuddin. 1998. Metode Penelitian. Pustaka Pelajar: Yogyakarta.

Claude Fernet, Sarah Genevieve Trepanier, Stephanie Austin, Marylene Gagne and Jacques Forest. 2015. Transformational Leadrship and optimal Functioning at work : On The Mediating Role Of Employees' Perceived Job Characteristics And Motivation. Work \& Stress: An International Journal of Work, Health \& Organisations. Vol. 29, No. 1, 11-31.

Muhamad. 2008. Metode Penelitian Ekonomi Islam: Pendekatan Kuantitatif. Rajawali Pers : Jakarta

Pabundu, Tika. 2005. Metode penelitian geografi. PT. Bumi Aksara : Jakarta.

Robbins, Stephen. 2006. Perilaku Organisasi. Prentice Hall, edisi kesepuluh

Robbins SP, dan Judge. 2008. Perilaku Organisasi Buku 2. Salemba. Jakarta.

Singarimbun, Masri dan Sofian Effendi. 2006. Metode Penelitian Survei ( Editor),. LP3ES, Jakarta.

Sugiyono. 2016. Statistika Untuk Penelitian. Cetakan Ketujuh. CV. Alfabeta. Bandung.

Undang-Undang RI Nomor 25 Tahun 2009 tentang Pelayanan Publik (LembarancNegara RI Tahun 2009 Nomor 112, Tambahan Lembaran Negara RI Nomor 5038).

Undang-Undang Nomor 28 Tahun 1999 tentang Penyelenggara Negara yang Bersih dan Bebas dari Korupsi, Kolusi dan Nepotisme, Citra Umbara, Bandung, 2016. 